\title{
PEMBUATAN VIRTUAL TOUR SEBAGAI SARANA PEMBELAJARAN PROGRAM STUDI MICE
}

\author{
Mardhiatul Husna, Erwinsyah Simanungkalit, Faulina \\ Politeknik Negeri Medan \\ Jalan Almamater No. 1, Kampus USU Padang Bulan, Medan - 20155, +62 61821 0436, Fax. \\ +62618215845 \\ mardhiatulhusna@polmed.ac.id
}

\begin{abstract}
Medan State Polytechnic is a vocational education that has D4 and D3 study programs, one of which is the Meeting, Incentive, Converence and Exhibition (MICE) study program. This study program was founded in 2007 until now only has a computer laboratory, language and 6 classrooms and a lecturer room 1. The MICE study program in its learning provides theory and practice with theoretical credits of $58=41 \%$ and practice of 87 = 59\% or 80: 143 hours. So far, students have practiced directly in the field (field study) such as convention halls in hotels andalso the field for the implementation of exhibitions. In current conditions, the event cannot be held, for that the mice study program must prepare a laboratory to support the MICE learning. This laboratory is equipped with equipment to create virtual tours such as the Insta $360^{\circ}$ One R Twin Edition camera and the Oculus Rift $S$ as a Virtual Reality (VR) System, the development of virtual tours using the MDLC (Multimedia Development Life Cycle) method was chosen because MICE students are used to it. designing and implementing events so that students are expected to be able to build and practice learning meetings, conferences, exhibitions in a better and interesting way, meanwhile for incentives students can see virtual tours and create virtual tour incentives. From this research it can be concluded that to be able to build a Virtual Tour is not difficult, it only requires knowledge of how to use the $360^{\circ}$ camera properly and use the VR System so that MICE students who do not have programming knowledge can still build their own Virtual Tour.
\end{abstract}

Keywords: Learning, Virtual Tour, Virtual Reality System, Oculus Rift S, MICE

\section{Abstrak}

Politeknik Negeri Medan merupakan pendidikan vokasional yang memiliki program studi D4 dan D3, satu diantaranya program studi Meeting, Insentive, Converence and Exhibition (MICE). Program studi ini berdiri sejak tahun 2007 sampai sekarang hanya memiliki laboratorium komputer, bahasa dan ruangan kelas 6 dan ruangan dosen 1. Program studi MICE dalam pembelajarannya memberikan secara teori dan praktik dengan SKS teori 58=41\% dan praktik 87=59\% atau jam 80:143. Selama ini mahasiswa melakukan praktik langsung ke lapangan (field study) seperti convention hall di hotel dan juga lapangan untuk pelaksanaan pameran. Dalam kondisi sekarang, event itu tidak bisa dilaksanakan, untuk itu program studi mice harus menyiapkan laboratorium untuk mendukung pembelajaran MICE tersebut. Pada laboratarium ini dilengkapi dengan peralatan untuk membuat virtual tour seperti kamera Insta $360^{\circ}$ One $R$ Twin Edition dan 
Oculus Rift S sebagai Virtual Reality(VR) System, pengembangan virtual tour mengunakan metode MDLC (Multimedia Development Life Cycle) metode ini dipilih karena mahasiswa MICE sudah biasa merancang dan melaksanakan event sehingga diharapkan mahasiswa dapat membangun dan mempraktikkan pembelajaran Meeting, Conference, Exhibition secara lebih baik dan menarik sementara itu untuk Insentive mahasiswa dapat melihat virtual tour dan membuat virtual tour insentive. Dari penelitian ini dapat disimpulkan untuk dapat membangun Virtual Tour tidaklah sulit hanya diperlukan pengetahuan bagaimana menggunakan kamera $360^{\circ}$ dengan baik dan penggunaan VR System sehingga mahasiswa MICE yang tidak memiliki pengetahuan pemprograman tetap dapat membangun Virtual Tour sendiri.

Kata kunci: Pembelajaran, Virtual Tour, Virtual Reality System, Oculus Ridft S, MICE

\section{PENDAHULUAN}

Politeknik Negeri Medan (POLMED) adalah Perguruan Tinggi Vokasional dengan jenjang pendidikan D3 dan D4 dan juga S2 Terapan. Politeknik Negeri Medan memiliki 6 jurusan dan 16 program studi jenjang Diploma 3, Sarjana Terapan(D4) dan Magister Terapan (S2), dengan mempunyai Visi : menjadi institusi pendidikan Tinggi Vokasi yang professional dan unggul.

Program studi yang ada di POLMED dalam menjalankan Proses Belajar Mengajar (PBM) nya menerapkan lebih banyak praktik dibandingkan teori. Program studi D4 MICE adalah satu program studi yang ada di POLMED dalam menjalankan PBM nya menerapakan praktik 59\% dan teori $41 \%$ dan ini sama dengan jam mengajar praktik 1548 dan teori 1440. Untuk mendukung kegiatan PBM ini prodi melakukan pembelajaran dengan terjun langsung ke lapangan atau venue event MICE. Dikarenakan saat ini Indonesia sedang dilanda wabah Corona, yang juga menyerang seluruh negara di dunia, maka hampir semua aktivitas mengalami pembatasan. Dalam kondisi seperti sekarang praktik mahasiswa tidak dapat dijalankan lagi dengan baik, praktik event MICE selama ini selalu menggunakan venue diluar kampus Polmed serta harus melakukan kunjungan ke lokasi venue seperti hotel dan lokasi wisata. Prodi MICE telah memiliki Laboratorum Komputer dan Bahasa, namun belum memiliki laboratorium khusus untuk praktik Event MICE. Kondisi pembatasan untuk mencegah penyebaran Covid-19 sekarang ini jelas sangat menganggu proses pembelajaran di MICE. Walaupun keadaan kelak akan pulih, namun dapat dipastikan kondisi new normal pastilah sangat ketat dengan berbagai pembatasan yang tentunya akan menyulitkan mahasiswa MICE ketika akan melakukan kegiatan sehubungan dengan event MICE di luar kampus. Hal ini jika tidak ditangani dengan tepat tentunya akan menganggu visi dan misi Politeknik Negeri Medan yaitu menghasilkan lulusan yang profesional dan unggul di bidangnya.

Untuk mengatasi hal tersebut perlu adanya laboratorium MICE yang mampu mengatasi kendala tersebut. Laboratorium ini harus dilengkapi dengan peralatan dan aplikasi yang mampu membantu mahasiswa untuk melihat kondisi di lapangan ataupun venue tanpa harus melakukan visitasi langsung ke lapangan. Aplikasi tersebut adalah Virtual Tour dengan Virtual Reality System menggunakan 
Oculus Rift S, dimana laboratorium ini akan mampu meningkatkan kualitas pembelajaran di program studi MICE. Secara langsung tentunya ini akan menjaga dan meningkatkan kualitas lulusan program studi MICE Selain itu, dengan adanya laboratorium MICE yang dilengkapi dengan aplikasi Virtual Tour dengan Virtual Reality System merupakan bagian dari upaya menjaga kualitas pelayanan publik dilingkungan Politeknik Negeri Medan serta untuk menjaga visi dan misi Politeknik Negeri Medan yaitu untuk menghasilkan lulusan yang profesional dan unggul tetap dapat terjaga.

Virtual tour adalah sebuah simulasi dari lokasi yang sesungguhnya, umumnya terdiri dari sequence video atau kumpulan foto [1]. Virtual Tour bisa menggunakan tambahan multimedia lain seperti efek suara, musik, narasi dan teks. virtual tour adalah sebuah simulasi dari lingkungan nyata, biasanya terdiri dari kumpulan foto-foto panorama, kumpulan gambar yang terhubung oleh hyperlink, atau video, atau virtual model dari lokasi yang sebenarnya, serta dapat menggunakan unsur-unsur multimedia lainnya seperti suara, musik, narasi dan tulisan[9].

Istilah virtual tour sering digunakan untuk menggambarkan berbagai video dan media berbasis fotografi. Kata "panorama" mengindikasikan sebuah pandangan yang tidak terputus, karena panorama bisa berupa sekumpulan foto memanjang ataupun hasil pengambilan video yang kameranya berputar/bergeser. Jika menggunakan kamera, maka virtual tour dibuat dari sebuah foto yang diambil dari sebuah titik pivot. Kamera dan lensa dirotasi berdasarkan apa yang disebut sebagai "nodal point" (suatu titik yang tepat berada pada bagian belakang lensa dimana cahaya berkumpul).

1) Pengertian gambar Panorama

Gambar panorama adalah beberapa gambar/foto dan digabungkan bersama-sama dengan menggunakan media digital untuk mendapatkan gambar/foto yang jauh lebih besar dan luas dengan skala atau ukuran serta detail yang tidak bisa dilakukan dengan foto standar. Panorama dibuat dengan menggunakan perangkat dasar fotografi yaitu kamera, lensa, tripod dan ditambah gimbal head agar tidak terjadi paralaks

2) Mengambil gambar Panorama

Dalam mengambil gambar panorama cara yang digunakan adalah berbeda dibandingkan dengan memotret pada umumnya. Dalam mengambil gambar panorama dibutuhkan sedikit perhitungan matematis yang dihitung berdasarkan peralatan yang digunakan. Kamera memiliki ukuran sensor yang berbeda dihitung dengan besarnya ukuran sensor, dan lensa memiliki luas pandang yang berbeda dihitung dari lebar fokalnya (focal length). Hal ini karena semakin besar sensor maka semakin lebar cakupan sudut pandangnya. Untuk membuat gambar panorama membutuhkan kamera yang sangat lebar cakupan sudut pandangnya. Sebagai contoh ketika menggunakan kamera dan lensa yang memiliki sudut pandang 90 derajat, maka untuk membuat 1 gambar panorama 360 derajat dibutuhkan minimal 5 gambar menghitung overlapping masing-masing gambar. 
3) Overlap Gambar Panorama

Gambar panorama dibuat dengan"menjahit" gambar yang satu dengan gambar lainnya. Proses ini disebut stitching. Proses stitching memerlukan perangkat lunak dalam penggunaannya. Proses ini bekerja dengan menjahit bagian gambar ke bagian gambar yang sama (overlapping). Proses stitching sangat rentan terhadap error jika terjadi kesalahan pada pengambilan gambar. Karena itu diperlukan perhitungan lensa dan kamera yang benar agar dapat terjadi proses overlapping. Overlapping yang baik adalah dengan mengambil 20\% -30\% bagian gambar untuk mendapatkan bagian gambar yang tajam agar tidak terjadi error pada saat proses stitching.

Namun semua itu sekarang dapat dengan mudah dilakukan dengan memanfaatkan teknologi yang sudah disediakan pada kamera $360^{\circ}$ seperti pada camera INSTA $360^{\circ}$ one R Twin Edition

Virtual reality adalah sebuah teknologi yang membuat pengguna atau user dapat berinteraksi dengan lingkungan yang ada dalam dunia maya yang disimulasikan oleh komputer, sehingga pengguna merasa berada di dalam lingkungan tersebut. Di dalam bahasa Indonesia virtual reality dikenal dengan istilah realitas maya. Teknologi virtual reality yang lebih awal adalah Peta Bioskop Aspen, yang diciptakan oleh MIT pada tahun 1977. Programnya adalah suatu simulasi kasar tentang kota Aspen di Colorado, dimana para pemakai bisa mengembara dalam salah satu dari tiga gaya yaitu musim panas, musim dingin, dan poligon. Dua hal pertama tersebut telah didasarkan pada foto, karena para peneliti benar-benar memotret tiap-tiap pergerakan yang mungkin melalui pandangan jalan kota besar pada kedua musim tersebut, dan yang ketiga adalah suatu model dasar 3 dimensi kota besar. Akhir tahun 1980 istilah "Virtual Reality" telah dipopulerkan oleh Jaron Lanier, salah satu pelopor modern dari bidang tersebut. Lanier yang telah mendirikan perusahaan VPL Riset pada tahun 1985, telah mengembangkan dan membangun sistem "kacamata hitam dan sarung tangan" yang terkenal pada masa itu. Secara umum, VR sudah dikembangkan cukup lama, tepatnya mulai dari tahun 1800-an. Berikut ditampilkan sejarah VR dari awal hingga saat ini.

a. 1800-an - Mulai muncul ide untuk membuat sebuah alternatif realitas seiring dengan mulai munculnya praktek fotografi.

b. 1838 - Ditemukan stereoskop pertama yang menggunakan dua cermin kembar untuk memproyeksikan sebuah gambar.

c. 1839 - Stereoskop tersebut dikembangkan menjadi View-Master dan kemudian dipatenkan satu abad kemudian pada tahun 1939.

d. 1956 - Morton Heilig yang memiliki latar belakang di industri Motion Picture Hollywoodmulai menginginkan orang-orang mampu merasakan suasana bagaikan masuk ke dalam sebuah film. Dibuatlah simulasi Sensorama yang dapat membuat penggunanya merasakan suasana lingkungan perkotaan bagaikan dengan menaiki sepeda motor. Sudah dilengkapi dengan multisensor stimulasi, sehingga penggunanya mampu melihat jalan, mendengar mesin motor berbunyi, merasakan getaran motor, dan mencium bau mesin motor di sebuah dunia yang didesain teknologi. 
e. 1960 - Morton Heilig kemudian mematenkan peralatan yang dinamakan dengan Telesphere Mask. Banyak investor yang kemudian tertarik bekerjasama.

f. Pertengahan 1980 - Mulai digunakan istilah "virtual reality". Adalah Jaron Lanier, founder dari VPL Research yang mulai mengembangkan peralatan virtual reality, termasuk google (kaca mata) dan sarung tangan yang dibutuhkan seseorang untuk merasakan pengalaman VR.

g. Saat ini - Setelah enam dekade dikembangkan dengan bantuan dana investor, kini VR bisa dinikmati secara luas dengan harga yang ekonomis, menggunakan peralatan berkualitas tinggi yang mudah diakses.

Virtual reality bekerja dengan memanipulasi otak manusia sehingga seolaholah merasakan berbagai hal yang virtual terasa seperti hal yang nyata. Bisa dibilang, virtual reality merupakan proses penghapusan dunia nyata di sekeliling manusia, kemudian membuat pengguna merasa tergiring masuk ke dunia virtual yang sama sekali tak bersentuhan dengan dunia nyata. Untuk dapat melakukan hal ini, tentu dibutuhkan berbagai perangkat tambahan. Paling minimalnya, jika Anda ingin merasakan masuk ke dalam dunia virtual reality, maka dibutuhkan sebuah headset VR, seperti misalnya yang kini banyak ditemukan di pasaran adalah Oculus Rift atau Samsung Gear VR.

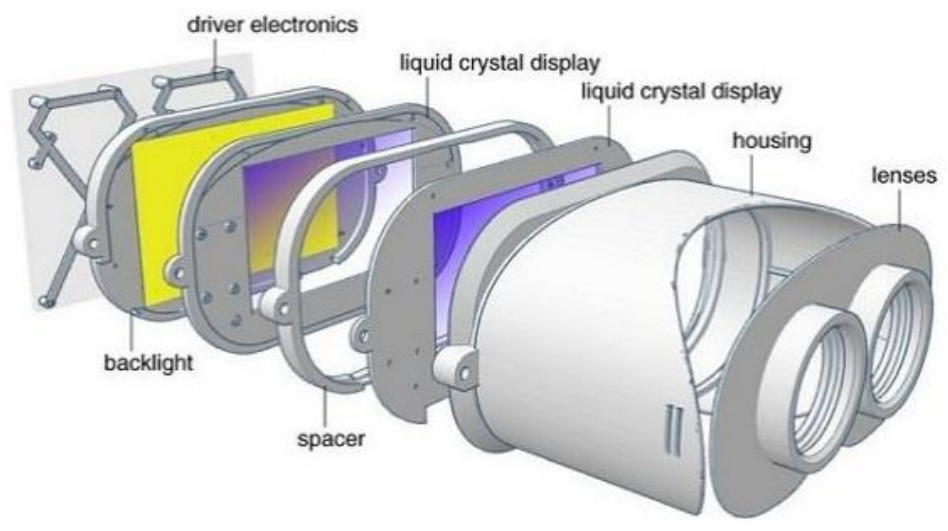

Gambar 1. Susunan komponen pada perangkat VR

Susunan komponen pada perangkat VR Secara kasat mata, headset VR ini berbentuk seperti kacamata selam, namun dengan lensa tertutup. Bagian yang seperti kacamata selam ini dinamakan sebagai VR box, yang merupakan tempat untuk meletakkan smartphone yang berfungsi memproyeksikan gambar virtual. VR yang menggunakan smartphone ini merupakan perangkat VR versi standar. Berbeda misalnya dengan VR headset yang sudah menggunakan teknologi canggih seperti Oculus Rift, di dalamnya bukan lagi menggunakan smartphone, melainkan sudah terdapat sebuah layar yang menampilkan video dan gambar virtual reality yang juga bisa terhubung dengan komputer menggunakan bluetooth. Ada 4 elemen penting dalam virtual reality.

Adapun 4 elemen itu adalah sebagai berikut: 
a. Virtual world, sebuah konten yang menciptakan dunia virtual dalam bentuk screenplay maupun script.

b. Immersion, sebuah sensasi yang membawa pengguna teknologi virtual reality merasakan ada di sebuah lingkungan nyata yang padahal fiktif. Immersion dibagi dalam 3 jenis, yakni:

1) Mental immersion, membuat mental penggunanya merasa seperti berada di dalam lingkungan nyata.

2) Physical immersion, membuat fisik penggunanya merasakan suasana di sekitar lingkungan yang diciptakan oleh virtual reality tersebut.

3) Mentally immersed, memberikan sensasi kepada penggunanya untuk larut dalam lingkungan yang dihasilkan virtual reality.

c. Sensory feedback berfungsi untuk menyampaikan informasi dari virtual world ke indera penggunanya. Elemen ini mencakup visual (penglihatan), audio (pendengaran) dan sentuhan.

d. Interactivity yang bertugas untuk merespon aksi dari pengguna, sehingga pengguna dapat berinteraksi langsung dalam medan fiktif atau virtual world. Pemakai melihat suatu dunia semu yang sebenarnya adalah gambargambar bersifat dinamis. Melalui Headphone atau speaker, pendengar akan mendengar suara yang realistis. Melalui headset, glove, dan walker, semua gerakan pemakai dipantau oleh sistem yang akan memberikan reaksi yang sesuai sehingga pemakai seolah-olah merasakan pada situasi yang nyata, baik secara fisik maupun psikologis.

Adapun beberapa penelitian terdahulu yang menjadi rujukan dari usul penelitian ini adalah :

a. Virtual 3D tour of the Neogene palaeontological heritage of Huelva (Guadalquivir Basin, Spain)[5] penelitian ini bertujuan untuk membangun sebuah virtual tour dalam format 3D pada Neogene palaeontological heritage.

b. A New Designing Methodology of Virtual Tour [2], Dalam makalah ini disajikan metodologi perancangan baru dari tur virtual on line struktur kompleks yang mengandung banyak tekstur. Metodologi ini memungkinkan untuk mengatasi beberapa keterbatasan model on-line yang dicirikan oleh pendekatan dan penyederhanaan. Keterbatasan ini diakibatkan oleh besarnya dimensi proyek berkualitas tinggi yang terkait dengan rekonstruksi bangunan kompleks dan yang memperlambat perkembangan dan penyebarannya.

c. Rancang Bangun Website Virtual Tour 360 derajat Cagar Budaya Kota Medan [6], penelitian ini membahas bagaimana membangun sebuah website yang dapat menampilkan foto panorama 360 derajat objek wisata di kota medan pada sebuah halaman website.

d. Design Methodology for 3600 Immersive Video Applications: The Case Study of a Cultural Heritage Virtual Tour [8], Makalah ini memperkenalkan satu set tugas desain dan teknik yang harus dipertimbangkan pada pengalaman dan lapisan desain interaksi proses desain untuk membuat aplikasi video $360^{\circ}$ tur Warisan Budaya 
e. Evaluating Museum Virtual Tours: The Case Study of Italy [4], makalah ini membahas bagaimana cara mengevaluasi virtual tour dengan mengunakan dua metode pengambilan keputusan yaitu AHP dan TOPSIS fazzy pada musim di itali.

f. Rancang Bangun Aplikasi Virtual Tour Monumen Mandala Merdeka berbasis Android [3], Penelitian ini bertujuan adalah merancang dan membangun aplikasi Virtual Tour Monumen Mandala Makassar berbasis Android. Metode penelitian pada penelitian ini adalah penelitian kualitatif dimana strategis yang digunakan adalah Design and Creation. Penelitian ini menggunakan metode pengumpulan data wawancara dan observasi. Metode perancangan menggunakan waterfall dan teknik pengujian yang digunakan adalah Black Box. Hasil dari penelitian ini adalah aplikasi Virtual Tour Monumen Mandala Makassar yang dapat menjadi media penyampaian informasi sejarah Pembebasan Irian Barat. Aplikasi ini sudah memvisualisasikan lingkungan pada Monumen Mandala Makassar, desain aplikasi menarik, serta informasi yang disajikan cukup lengkap mengenai Monumen Mandala Makassar tersebut.

g. Virtual Reality Tour of the "Focus of Favorites" Exhibition at the Gilcrease Museum [7], Makalah ini membahas tur virtual reality dari pameran "Focus on Favorites, Masterworks from the Gilcrease Collection" di Gilcrease Museum di Tulsa, Oklahoma. Tur museum virtual menggabungkan foto, rekaman audio, dan digitalisasi. Tujuannya adalah untuk menciptakan pengalaman interaktif yang menarik dan mandiri.

h. Nicola building virtual tour; considering simulation in the equity of experience concept [1], penelitian ini menguji bagaimana inspeksi sebuah Gedung mengunakan virtual tour dengan inspeksi yang dilakukan secara langsung yang menyimpulkan bahwa inspeksi secara virtual mendapat respon yang positif.

Perbedaan antara penelitian ini dengan penelitian yang dilakukan sebelumnya adalah luasnya cakupan venue/tempat yang akan dibuat virtual tour dan dilengkapi dengan Virtual Reality System menggunakan Oculus Rift S serta metode dalam membangun Virtual Tour sehingga akan sangat memudahkan mahasiswa dalam melakukan kegiatan pembelajaran yang harus melakukan kunjungan fisik dapat di kurangi dalam masa pandemic sekarang ini.

\section{METODOLOGI PENELITIAN}

Metodologi yang digunakan adalah MDLC (Multimedia Development Life Cycle), yang terdiri atas 6 tahapan seperti gambar 2.1 


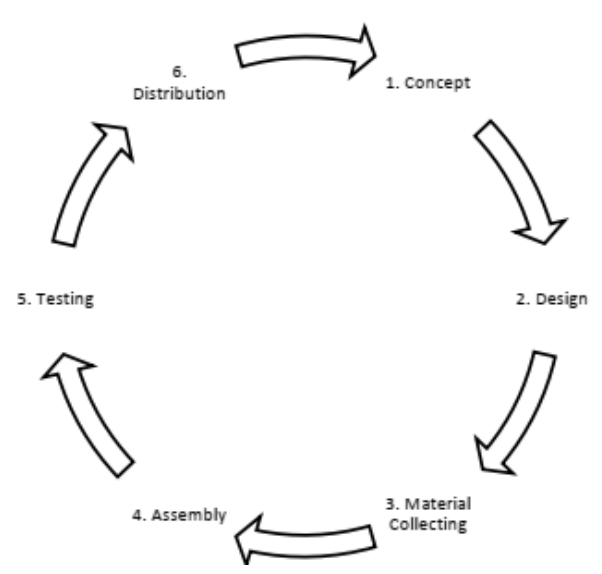

Gambar 2.1 Tahapan Pengembangan MDLC [6]

Uraikan secara rinci metode yang akan digunakan meliputi:

\subsection{Tahapan-Tahapan Penelitian}

a. Concept

Tahap concept (pengonsepan) adalah tahap untuk menentukan tujuan dan siapa pengguna program (identifikasi audiens).

b. Design

Design (perancangan) adalah tahap pembuatan spesifikasi mengenai arsitektur program, gaya, tampilan dan kebutuhan material/bahan untuk program.

c. Material collecting

Material collecting adalah tahap pengumpulan bahana yang sesuai dengan kebutuhan yang dikerjakan.

d. Assembly

Tahap assembly adalah tahap pembuatan semua objek atau bahan multimedia. Pembuatan aplikasi didasarkan pada tahap design, seperti storyboard, bagan alir dan struktur navigasi.

e.Testing

Tahap testing (pengujian) dilakukan setelah menyelesaikan tahap pembuatan (assembly) dengan menjalankan aplikasi/program dan melihat apakah ada kesalahan atau tidak.

f. Distribution

Pada tahap ini, aplikasi akan disimpan dalam suatu media penyimpanan. Jika media penyimpanan tidak cukup untuk menampung aplikasinya, kompresi terhadap aplikasi tersebut akan dilakukan

\subsection{Lokasi Penelitian}

Politeknik Negeri Medan Program Studi MICE 


\subsection{Parameter Pengukuran dan Pengamatan}

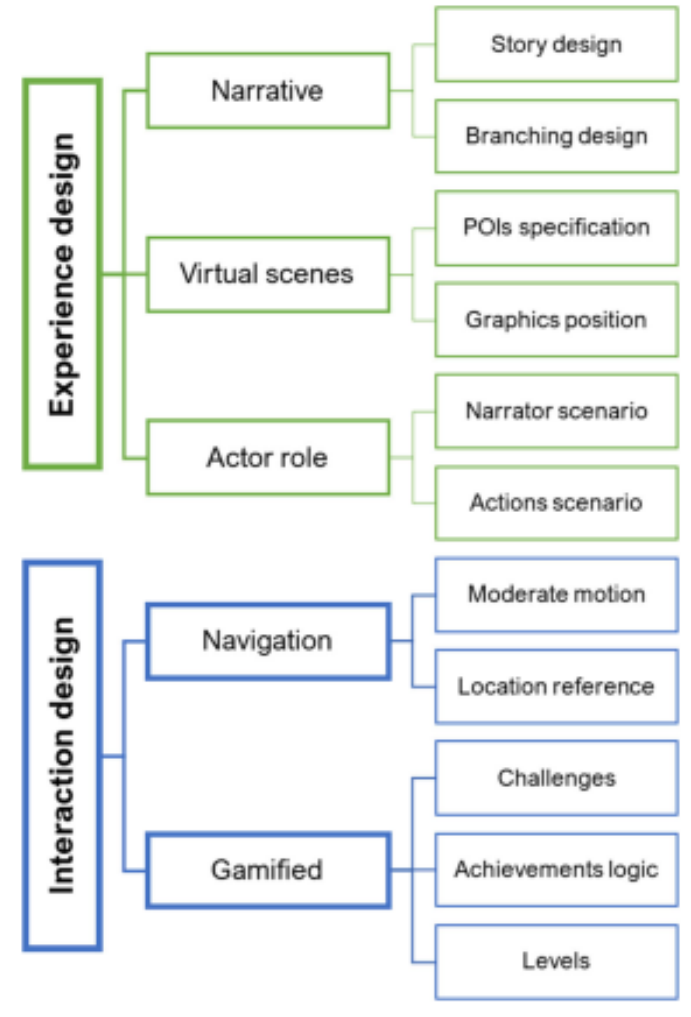

Gambar 2.2 Desain aspek yang di amati dan di ukur dalam Virtual Tour

\subsection{Model Penelitian}

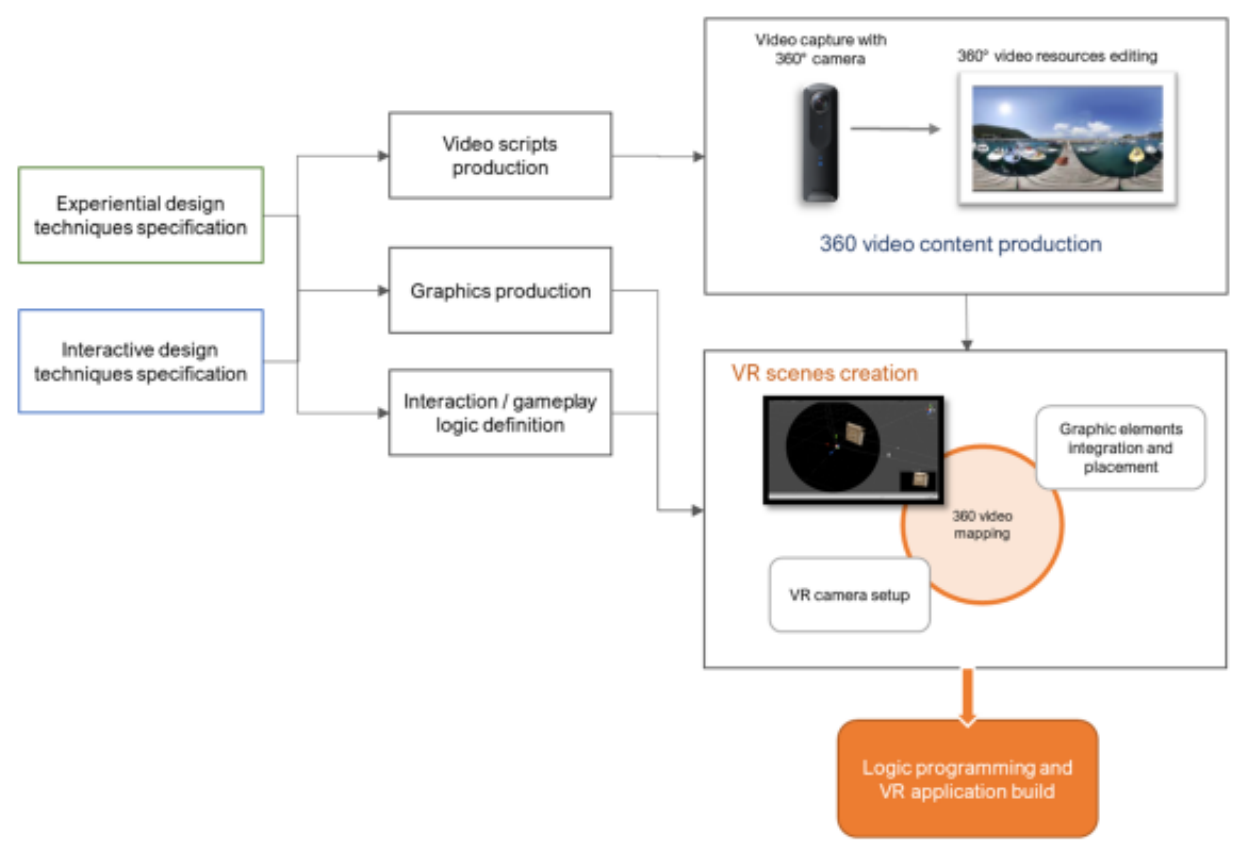

Gambar 2.3 diagram pengembangan model aplikasi virtual tour 


\section{HASIL DAN PEMBAHASAN}

\subsection{Hasil Penelitian}

Penelitian ini menghasilkan sarana pembuatan (laboratorium) virtual tour yang dilengkapi dengan virtual reality, yang dapat digunakan sebagai sarana untuk membantu pembuatan media pembelajaran dan sarana pembuatan media promosi khususnya di program studi MICE dan politeknik Negeri Medan secara umum, untuk dapat membuat virtual tour dengan mudah dan cepat maka diperlukan peralatan pendukung sebagai berikut:

1) Kamera insta360 R twin Edition

2) Oculus Rift S Virtual Reality System

3) Komputer dengan spesifikasi VR Ready

Dengan tersedianya sarana peralatan tersebut nantinya prodi MICE atau mahasiswa MICE dapat membangun Virtual tour sendiri dengan mudah, dengan mengambil data foto $360^{\circ}$ dari lokasi yang ingin di buat virtual tour dan tinggal mengolahnya dengan aplikasi pembuat virtual tour yang sekarang ini sudah banyak tersedia dan dapat di publish melalui internet, hal ini di harapkan bisa menjadi sebuah usaha mandiri prodi MICE dan menjadi bekal mahasiswa untuk dapat berwirasausaha di bidang Virtual tour.

\subsection{Pembahasan}

Dalam penelitian ini ada beberapa tahapan yang di lakukan yaitu:

a. Tahap mempersiapkan peralatan yang di butuhkan

Pada tahap ini peneliti mempersiapkan peralatan pendukung yang dibutuhkan dalam pembuatan virtual tour, peralatan yang dibutuhkan adalah:

1) Kamera $360^{\circ}$

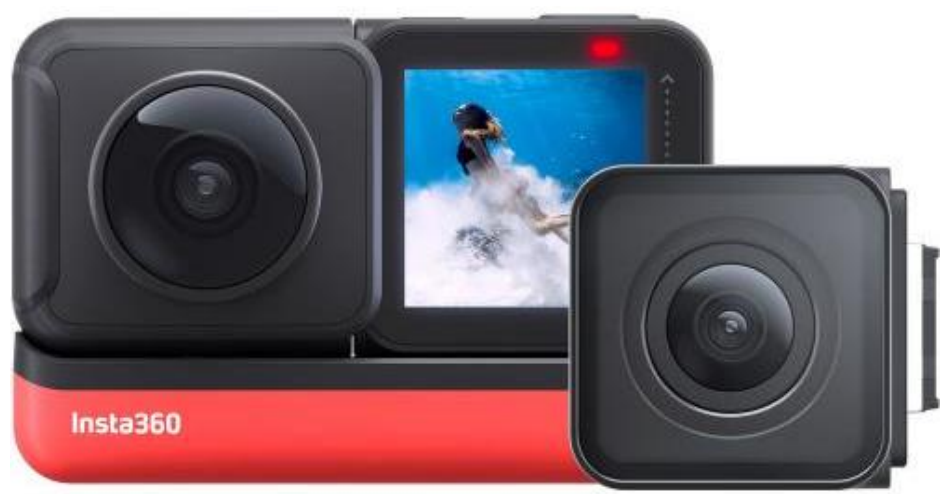

Gambar 3.1 Insta360 one R twin Edition

Kamera yang dipilih peneliti adalah insta360 one R twin Edition, kamera ini memiliki kecepatan pengambilan yang baik, juga dilengkapi dengan kamera $4 \mathrm{~K}$ untuk pengambilan gambar yang lebih baik. FlowStatenya mencapai stabilisasi seperti gimbal tanpa gimbal. Berkat algoritma pendeteksian adegan baru, rekaman Anda tetap jernih dan stabil bahkan dalam cahaya redup. Fitur Invisible Selfie Stick ONE R memungkinkan menangkap sudut udara yang mudah dan perspektif yang unik dengan menggunakan Dual-Lens 360 Mod. Dengan mengunakan kamera 360 peneliti tidak perlu melakukan ovelap saat pengambilan foto karena sudah ditangani langsung oleh kamere 
360 sehingga tidak lagi diperlukan proses untuk mengabung-gabungkan foto seperti bila membuat foto 360 atau panorama dengan kamera DSLR sehingga sangat menghemat waktu pengerjaan pembuatan virtual tour.

Adapun kelebihan kamera $360^{\circ}$ secara umum adalah:

2) Kamera $360^{\circ}$ memiliki lensa fisheye

Ada dua atau lebih lensa fisheye yang terdapat pada kamera $360^{\circ}$ dengan jangkauan 180 derajat. Tiap lensa yang dimiliki mampu mengambil dan menggabungkan gambar dengan tajam dan akurat, pada waktu bersamaan.

3) Memiliki bidang pandang tak terbatas

tidak dipungkiri, dengan kamera biasa, hasil jepretan atau rekaman yang dihasilkan memiliki bidang padang yang terbatas. Akibatnya, akan lebih sulit jika ingin mengambil banyak subjek sekaligus. Namun, dengan kamera $360^{\circ}$, bidang pandang menjadi lebih luas dari segala sisi.

4) Dapat dikombinasikan dengan teknologi Virtual Reality

Teknologi Virtual Reality (VR) merupakan perangkat digital yang bisa menghadirkan pengalaman virtual kepada penggunanya. VR sudah banyak digunakan di berbagai bidang, seperti militer, transportasi, kesehatan, ekonomi, media, dan terlebih hiburan.

VR sendiri rupanya meningkatkan minat pengguna terhadap komponen pendukung lainnya, seperti kamera $360^{\circ}$ derajat. Apalagi, hasil rekaman pada kamera $360^{\circ}$ bakalan lebih asyik ketika dilihat dengan menggunakan perangkat VR, penguna bisa merasa seperti berada di dalam rekaman karena hasilnya terasa begitu real

5) Terhubung dengan ponsel lewat Wi-Fi Direct atau Bluetooth Lewat Wi-Fi Direct atau Bluetooth, kamera $360^{\circ}$ juga sudah bisa tersambung ke ponsel. Tentunya, hal ini memudahkan untuk melihat objek yang sedang dibidik, lalu mentransfer dan menyimpanya langsung di galeri ponsel.

Dalam penelitian ini kamera ini digunakan untuk mengambil foto objek yang akan dijadikan virtual tour

6) Oculus Rift $S$
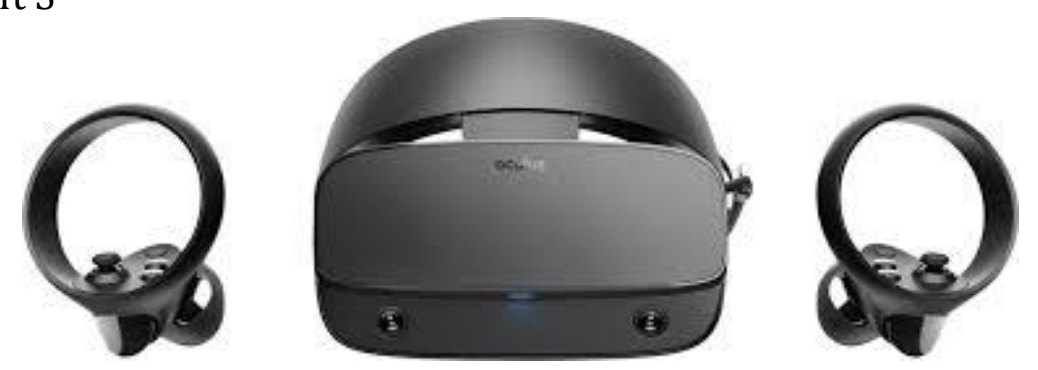

Gambar 3.2 Oculus Rift S

Oculus Rift $\mathrm{S}$ merupakan penerus dari Oculus Rift generasi pertama dan membawa sejumlah peningkatan yang cukup signifikan. Berbeda dengan seri lainnya seperti Oculus Go dan Oculus Quest, Oculus Rift S harus tersambung ke PC atau Laptop. 
Oculus melakukan pengembangan Oculus Rift S bersama Lenovo supaya kenyamanan pengguna dapat semakin meningkat. Tidak seperti generasi pertama yang bobotnya terfokus pada satu titik saja, Oculus Rift S lebih nyaman digunakan karena pemerataan bobot yang baik dan desain Halo Strap oleh Lenovo yang meningkatkan keseimbangan Oculus Rift S saat sedang digunakan.

Oculus Rift S menempatkan dua lensa mirip google di depan mata yang memberikan tampilan 3D stereoskopis dari dunia virtual tempat penguna berada. Kombinasi sensor pada perangkat ini kemudian menghitung gerakan di dunia nyata lalu kemudian menerjemahkannya menjadi gerakan dalam dunia virtual.

Dalam penelitian ini perangkat Virtual Reality Oculus Rift S digunakan untuk dapat pengalaman virtual tour yang lebih terasa nyata dengan memanfaatkan fasilitas virtual desktop yang disediakan oleh perangkat VR System.

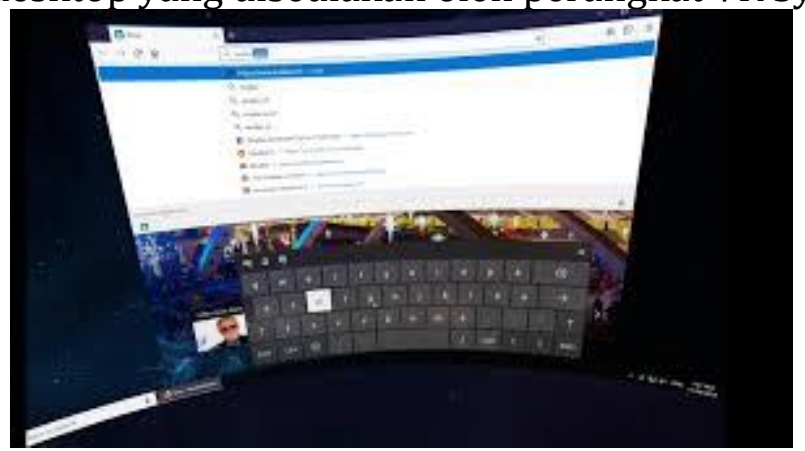

Gambar 3.3 Virtual desktop di VR System Oculus

Untuk dapat menjalankan Virtual Desktop sangat mudah di control panel oculus bila sudah mengunakan headset VR, tinggal memilih dari menu yang sudah di sediakan seperti gambar berikut.

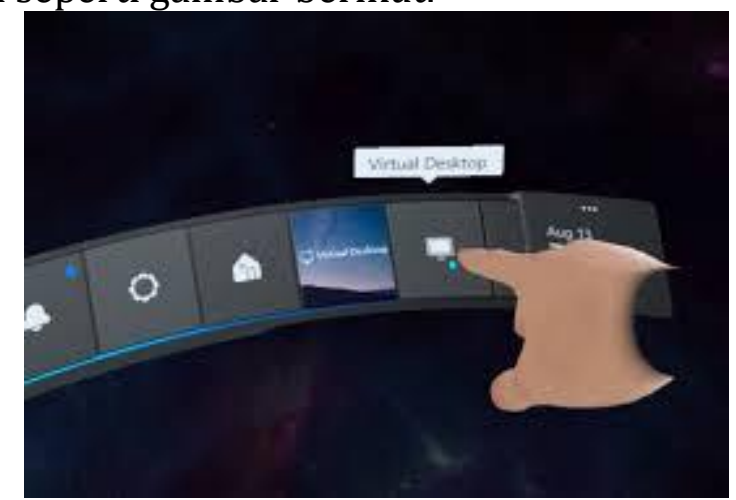

Gambar 3.4 Control panel Oculus untuk Virtual Desktop

7) Komputer VR Ready

Komputer VR Ready adalah perangkat komputer yang memenuhi standar minimal untuk dapat menjalankan aplikasi Virtual Reality, komputer yang termasuk VR Ready memiliki spesifikasi Minimum yang cukup tinggi untuk penelitian ini di bangun sebuah komputer dengan spesifikasi sebagai berikut:

1) Kartu Grafis: NVIDIA GTX 1070 
2) Processor atau CPU: Intel i5-10400F

3) RAM: 8 GB

4) USB Ports: $3 x$ USB 3.0 ports

5) Video Output: Kompatibel HDMI 1.3

6) Sistem Operasi: Windows 10

Dengan spesifikasi tersebut komputer tersebut sudah termasuk VR Ready dan dapat dilihat juga dengan memanfaatkan aplikasi pengecekan VR Ready dari aplikasi SteamVR Performance Test

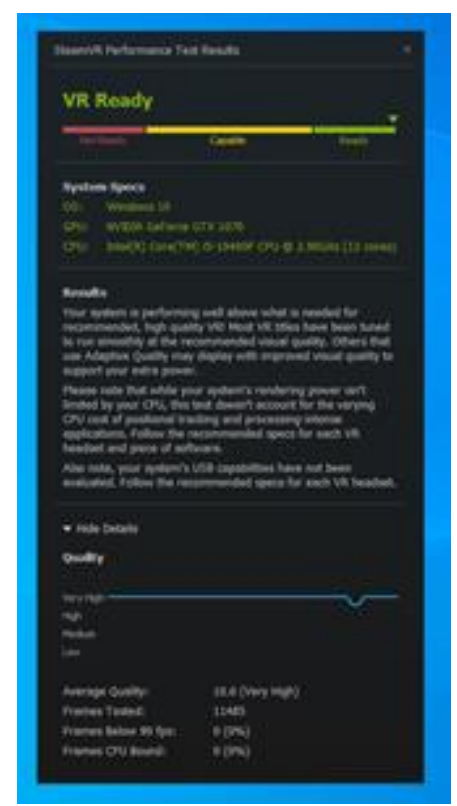

Gambar 3.5 Hasil test SteamVR Performance Test pada komputer yang di bangun

b. Tahap mempersiapkan software yang di butuhkan

Untuk melakukan pembuatan virtual tour dengan Virtual Reality System diperlukan beberapa perangkat lunak yang harus terinstall di komputer antara lain INSTA360 300 studio digunakan untuk mengambil dan mengedit foto dari kamera $360^{00}$ yang digunakan, Oculus Home sebagai interface perangkat Oculus Rift $S$ yang digunakan, dan aplikasi insta $360^{\circ}$.apk yang di jalankan di smartphone sebagai controller kamera $360^{00}$, selain itu untuk dapat membuat dam mempublish virtual tour dapat menggunakan beberapa aplikasi berikut:

1) Tour Creator Google https://arvr.google.com/tourcreator/

Aplikasi online ini adalah layanan gratis dari google untuk dapat membuat virtual tour.

2) Virtual tour $360^{\circ}$ Melalui Google Street View

3) Atau menggunakan aplikasi berbayar yang mulai banyak tersedia di internet seperti yang disediakan pada web kuula.co atau cupix.com

c. Tahap mengumpulkan data dengan pengambilan foto $360^{00}$ dengan kamera INSTA $360^{\circ 0}$ One R Twin Edition 
Pengumpulan data foto $360^{00}$ dilakukan dengan mengunakan Teknik pengambilan yang sesuai dengan virtual tour yang ingin di hasilkan dan sesuai dengan konsep virtual tour yang di rancang sebelumnya.

d. Tahap pembuatan Virtual tour

Setelah semua material atau data foto $360^{00}$ sudah terkumpul barulah dibangun aplikasi virtual tour yang diinginkan dan hasilnya dapat di embed kedalam website yang diinginkan, hasilnya dapat di lihat langsung atau dapat menggunakan Virtual Reality Headset agar dapat merasakan tour yang terasa lebih nyata.

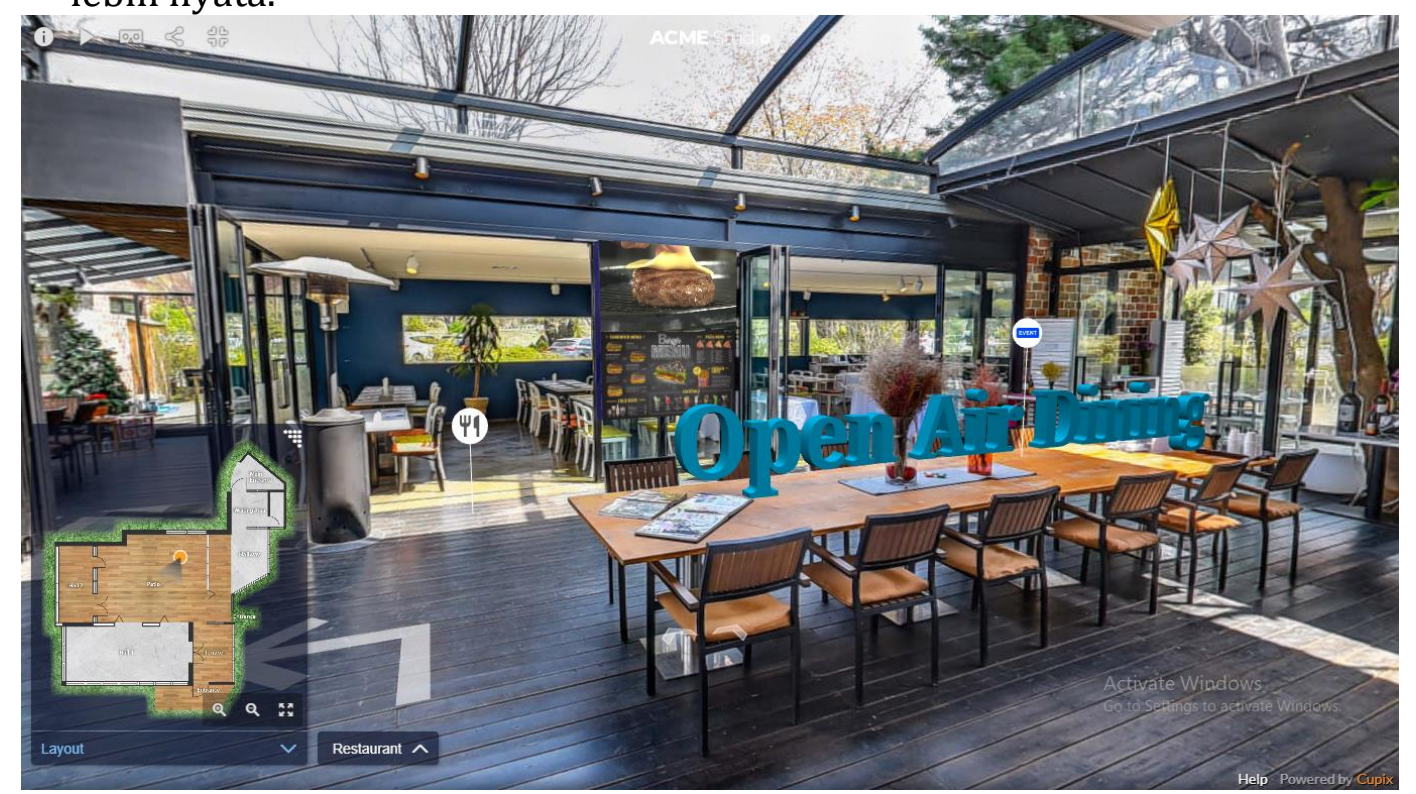

Gambar 3.6 contoh Virtual Tour (cupix.com)

\section{SIMPULAN}

Dari hasil penelitian ini dapat disimpulkan sebagai berikut :

a. Untuk dapat membangun Virtual Tour dengan Virtual Reality terutama mengunakan perangkat Oculus Rift $S$ tidak memerlukan pengetahuan pemprograman seperti Unity cukup hanya memanfaatkan fasilitas virtual desktop yang di sediakan Oculus

b. Diperlukan waktu yang cukup lama untuk dapat mengumpulkan data dan membangun Virtual Tour yang lebih sempurna dan menarik

c. Penguasaan Teknik dalam pengambilan foto $360^{\circ}$ sangat menentukan hasil pengambilan foto dan Virtual Tour yang dihasilkan

d. Banyak sekali aplikasi yang tersedia untuk dapat membangun virtual tour berbasis virtual reality system, sehingga mempermudah untuk membangun virtual tour sendiri.

e. Mahasiswa MICE dapat membangun dan mengunakan Virtual tour dengan baik. 


\section{DAFTAR PUSTAKA}

[1] Colasante, M. (2011). Nicola building virtual tour; considering simulation in the equity of experience concept. ASCILITE 2011 - The Australasian Society for Computers in Learning in Tertiary Education.

[2] Dimauro, G., Impedovo, S., \& Orabona, V. (2006). a New Designing Methodology of Virtual Tour. January. http://citeseerx.ist.psu.edu/viewdoc/summary?doi=10.1.1.522.6797

[3] Fitri, M. O. (2016). Rancang Bangun Aplikasi Virtual Tour Monumen Mandala Berbasis Android. Jurnal Informatika Sains Dan Teknologi, 1(1).

[4] Kabassi, K., Amelio, A., Komianos, V., \& Oikonomou, K. (2019). Evaluating Museum Virtual Tours: The case study of Italy. Information (Switzerland), 10(11), 1-11. https://doi.org/10.3390/info10110351

[5] Martínez-Graña, A. M., Bajo, I., González-Delgado, J. A., Cárdenas-Carretero, J., Abad, M., \& Legoinha, P. (2018). Virtual 3D Tour Applied to the Paleontological Heritage of the Neogene of Sevilla (Guadalquivir Basin, Spain). In Geoheritage. https://doi.org/10.1007/s12371-017-0247-y

[6] Said, R. A., \& Hasibuan, M. S. (2012). Rancang Bangun Website Vitrual Tour $360^{\circ \circ}$ Cagar Budaya Kota Medan. Journal Online Jaringan Pengajian Seni Bina, January 2016.

[7] Smith, W, Couch, A, Pickering, R, \& ... (2016). Virtual Reality Tour of the "Focus of Favorites" Exhibition at the Gilcrease Museum. ... Visualisation and the Arts, scienceopen.com, https://www.scienceopen.com/hosteddocument?doi=10.14236/ewic/EVA2016.36

[8] Argyriou, L., Economou, D., \& Bouki, V. (2020). Design methodology for $360^{\circ}$ immersive video applications: the case study of a cultural heritage virtual tour. Personal and Ubiquitous Computing. https://doi.org/10.1007/s00779-020$\underline{01373-8}$

[9] Handjojo, F. (2013). Perancangan Dan Implementasi Aplikasi Content Management System Dengan Format Virtual Online Tour. Jurnal Teknik Informatika Universitas Tanjungpura, 1, 1-6. 